\title{
THE MYTH OF THE BLACK MATRIARCHY UNDER SLAVERY
}

\section{Mike Meacham}

University of Kansas

Mid-American Review of Sociology, 1983, Vol. VIII, No. 2:23-41

When attempting to answer the question of why blacks have not obtained equality, social scientists have often relied on historical data. However, interpretations of this data have led to widely varying conclusions, especially concerning the historical development of the black American family.

One line of argument, advocated by W.E.B. DuBois (1903), Stanley M. Elkins (1963), and E. Franklin Frazier (1948), among others, claims that pressures on the black family from slavery to the present have resulted in a family that inadequately socializes its members. Some corroborative evidence is found in slave autobiographies. Fredrick Douglas writes, "of my father I know nothing. Slavery had no recognition of fathers" (1962:27). Booker T. Washington, in a similar vein wrote "Of my father I know even less than my mother. I do not even know his name" (1965:15-16). Elkins concludes that black families were not viable for socialization (1963:305). Frazier believes that "the negro mother remained the most stable and dependable element during the entire period of slavery" (cited in Rudwick, 1971:66). Perhaps the culmination of this viewpoint came in the study done by Glazer and Moynihan (1963) which argues:

Perhaps most important-its influence radiating to every part of life-is the breakdown of the negro family structure. For this, most of all, white America must accept responsibility. It flows from centuries of oppression and persecution of the negro male (cited in Rainwater and Yancy, 1967:130).

More specifically, they go on to state:

In essence the Negro community has been forced into a matriarchal structure which, because it is so out of line with the rest of American society, seriously retards the progress of the group as a whole (cited in Rainwater and Yancy, 1967:29). 
Glazer and Moynihan conclude, "The negro is only an American and nothing else. He has no values and culture to guard and protect" (1963:51). The problem with this line of reasoning is that it can easily become a "blaming the victim" argument. Spradley (1980:17) states that "Culture descriptions can be used to oppress people or to set them free." Although Glazer and Moynihan place the blame on white Americans, they imply that the trouble is an outgrowth of the blacks' own family structure. They have also negated the black male as an integral part of the black family.

Another line of reasoning, largely in opposition to the above, states that black families are capable socializers but are more reliant on the extended family network than on the nuclear family (see especially Stack, 1974). ${ }^{1}$ These theorists believe that blacks tend to have the same goals as whites, but have adopted new means of reaching them. ${ }^{2}$

Spradley describes the problem of assuming that everyone in American culture has similar goals.

Our culture has imposed on us a myth about our complex society-the myth of the melting pot. Social scientists have talked about 'American Values' as if it included a set of values shared by everyone living in the United States. It has become increasingly clear that people live by many different cultural codes $(1980: 15)$.

The view that black families are viable, but different is found in passages throughout the literature. Genovese writes:

by asserting himself as the protector of black women and domestic peace, the slaveholder asserted himself as the paterfamilias, and reinforced his claim of being sole father of a family of both black and white (1974:483).

Blassingame concludes that "Under such a regime slave fathers had little or no authority" (1976:483).

The benefit of the extended family thesis is that it acknowledges, like Baechler, that the "aim of all life in society is to insure security from outside threat whether from men, animals, or things" (1970: 25). The black community had taken steps within the family to do this by extending the family network. Blassingame points out that the distinctive black culture under slavery gave them a strong sense of group solidarity that survived oppression (1976:75).
Various reports of incidents under slavery also uphold this thesis. Genovese writes that "Mingo White's father upon being sold did nothing unusual when he charged a male friend with responsibility for looking after his son. A principle of stewardship had arisen in the quarters" (1974:492). Thrope concludes that efforts such as these are tributes to slaves' genius and self-esteem (Gilmore, 1978:52).

Although some historical evidence supports it, the contemporary ramifications of the extended family thesis are very critical of the black male and should be examined. Both Leibow in Tally's Corner (1967:63) and Stack in All Our Kin (1974:108) portray the black males' role as economically exploiting black women. Is this the real role of black males? Are black men really problematic in the black family because they have been somehow ruined by oppression?

I believe the answer to both questions is no. Spradley points to the inherent weakness of inadequately discussing male roles. "Any explanation of behavior which excludes what the actors themselves know, how they define their actions, remains a partial explanation that distorts the human situation" (1980:16).

This article will deal with only one historical epoch in the history of black American family development-that of slavery. Slavery is chosen because, if the previously discussed arguments are correct, the strain on black families should be most evident under the worst system of domination. Also, the above arguments either explicity or implictly state that the oppression began under slavery. In short, then, this paper investigates these arguments at their source.

I will concentrate on the role of the male, specifically the husband, under slavery. Moses (1982:53-54) explains the problem with denying a strong male role under slavery.

The emphasis on the myth of a black male who put the welfare of his master's family above his own and who defended his mistress while his own loved ones remained in bondage was obviously not a flattering one. It contributed to a desexualized image of a black male and to the myth of the ignorant, stupid darky contented to remain in bondage. In later Victorian American, the usefulness of the myth was one that obviously had negative potential, for it could also be used to buttress the argument that black people were naturally servile. 
In addition, this paper will borrow ideas from both the "Frazier thesis" and the "Stack thesis," but instead of arguing that the strength of black females somehow kept males from becoming full, contributing humans, I will argue, that greater equality between the sexes supported males instead of undermining them (Queen et al., in press), and that instead of wrecking the family, slavery only served to force blacks to create new norms that supported the nuclear family, which they had come to value as their own family unit (Genovese, 1974:451-452).

\section{Theoretical Problems}

Genovese observes that the slaveholders were caught in a contradiction: By breaking the willpower of the slaves they lost good workers, while by encouraging spirit in slaves they created problems of rebellion and runaways (1974:480-490). One way for the planter to deal with this problem was to encourage the growth of black families, thereby developing a sense of responsibility among the slaves to their families and a means of threat by separation. Fogel and Engerman (1974:128) claimed that planters encouraged unions in spite of state laws forbidding them. Blassingame (1976:151) found this to be equally beneficial to the slave. "The main thrust of my argument was that slaves generally had monogomous unions held together by affection rather than by law and that the family contributed to the bondsman's selfesteem and survival."

In economic terms, Marx states that because slaves were a valuable commodity and treated as such, they were mistreated extensively only when a new and renewable supply could be obtained from the middle states (1978:154), but Catton (1961:242) shows that supply was already waning by the time of the American Civil War. There is within Marx's argument recognition that, while the system of slavery was extremely brutal, the complete domination of slaves was not always in the master's interests, especially in the later years of slavery in the United States.

At the psychological level, Piaget's work is suggestive. The crux of his theory of Cognitive Development is that the most important time in individual growth is before late adolescence (Rosen, 1977:1029 ). If Piaget is correct, the black male may have developed a sense of self well before the worst ravages of slavery took their toll. Blassingame illustrates the reasons why.
The period of early childhood and the equality of playmates which transcended color sometimes obscurred a young slave's vision of bondage. During this period many young blacks had no idea that were slaves. ... Fredrick Douglas reported that during his childhood, it was a long time before I knew myself to be a slave. This was true he said, because the first seven or eight years of a slave boy's life are as full of sweet content as those of the most favored and petted white children of the slaveholder....(F)reed from all restraint in his life and conduct-a genuine boy, doing whatever his boyish nature possessed (1976:96).

As a child, the slave's development came from a variety of sources. Authorities on slavery often point to the strong effect the subcommunity had on the child slave (Genovese, 1974:83), and to the fact that despite the planters belief that rearing in the quarters emphasized his authority, male slave children were taught to protect females from exploitation or excessive domination, even to the point of direct confrontation with whites (Blassingame, 1976:99). Finally, the role of the black mother was very strong and encouraged by the master (Fogel and Engerman, 1974:137). Since most slave boys had the advantages of freedom, training in at least one traditional male role (protection), and a strong mother influence, one must question whether the slaves' personalities were crushed upon his entrance into the system (at about age ten for some irregular work, according to Genovese, 1974:97).

Theories drawn from Marx and Piaget challenge the assumption that black males were an unimportant part of the slave subculture. When Weber's concept of a pariah people is applied to this instance one finds a systematic critique of the entire argument that slaves were severely crushed by oppression. He described pariah people as denoting

... a distinctive heredity social group lacking autonomous political organization and characterized by internal prohibitions against commensuality and intermarriage originally founded on magical, tabooistic, and ritualistic injunction. Two additional traits of pariah people are political and social disprivilege and a far-reaching distinctiveness in economic functioning (1978:493). 
This definition seems to describe slaves very well. The important point here, however, is that pariah people form special religious adaptations to their plight (Weber, 1978:493). Through these adaptations, a strong and viable subculture can evolve. The crucial aspect of pariah religions is that the people believe they are a selected group with the special favor of the diety. Kilson relates this to the slaves:

In the black experience the slave trade ... endowed the black man with a special aura of righteousness, indeed that same righteousness that has been applied to the oppressed and wretched of the earth since the birth of Christianity (quoted in Moses, 1982:9).

Moses (1982:10) concludes that blacks saw this struggle as a moral crusade.

The role of the prophet, an additional characteristic of pariah people, is also prevalent in black religion and, religious leaders were very important to the people under slavery. Black slave religion was tinged with beliefs and practices transplanted from Africa (Genovese, 1974:332), which focused on the power of the male priest as a leader among the populace (DuBois, 1903:5). The African religions recognized witchcraft and sorcery as powerful influences on the behavior of the parties it was used against. The conjurer then became a powerful influence on the plantation (Blassingame, 1976:45), both black and white.

Meanwhile, slaves adopted the predominate religion of the society they had entered, but, with an important shift in perspective. Black preachers emphasized the lowly station of Christ (Genovese, 1974: 242); Blassingame, (1976:64), thereby portraying their lowly status as that chosen by God.

It is among black preachers that slave children could find strong male models of influence and respect (Genovese, 1974:493). DuBois describes them:

The preacher is the most unique personality developed by the Negro on American soil. A leader, a politician, an orator, a 'boss,' an intriger, an idealist-all these he is an ever too, the center of a group of men, now twenty, now a thousand in number. The combination of a certain adroitness with deep-seated earnestness, of tact with consummate ability, gave him his preeminence and helps him to maintain it (cited in Genovese, 1974:258).
Black preachers and conjurers gained respect not only among the slaves, but among the white population as well. Blacks were often asked to officiate at white schools, funerals, and at other places and events (Genovese, 1974:256). White ladies even asked conjurers for fortunes and love potions (Blassingame, 1976:49). Such inconsistency between the status of slave and that of preacher or conjurer met with resistance, and at times black preachers were whipped or otherwise persecuted (Genovese, 1974:256), but the ideals they represented within black culture never died. ${ }^{3}$

The effect of religion on the slave was very strong. Blassingame claims it often overcame the slave's fear of his master (1976:75); gave him a sense of personal worth and communal fellowship; and helped preserve his mental health $(1976: 206)$. Beyond these things slave religion exhibited ressentiment ${ }^{4}$ as a means of expressing the slave's desire for freedom (1976:66).

The efforts of the black preachers were remembered after slave emancipation. Ex-slaves recalled their accomplishments well after 1865 (Genovese, 1974:257). Their original thesis, characterized by ressentiment is still a central theme of black religion. "The otherwordliness that characterizes black religion for so much of its history implies a rejection of the popular faith that America was the best of all possible worlds" (Killian, 1975:121).

\section{Case Histories}

Many case histories attest to the fact that male slaves had strong feelings towards their wives and children. Genovese quotes a crippled slave at an auction: "Yes, sire, I kin do ez much ez ennybody and marsters, if you'll only buy me and de chillum with Martha Ann, God knows I'll work myself to death for you" (1974:456). Billingsley (1968:65) quotes another slave: "The greatest desire of my life is to give my children an education and to have them form virtuous habits." The extended family was important among African cultures and marriages were most commonly monogomous. The kinship unit provided care for children usually from the father's sister; however, it was mainly the father who shouldered the role of the care and protection of his children in all West African societies (Billingsley, 1968:43).

Patterns of descent did vary in Africa (patrilinear in the Ibo, Yoruba, and Dahomean tribes; matrilinear in the Ashanti tribe; and both in the Yako tribe). The father's dominance was apparent even in matriarchal societies where he had few, if any legal rights over his 
children. In these societies, the wife's older brother carried out any legal responsibilities, leaving the moral and economic responsibilities to the father. These obligations became a point of honor and privilege throughout West Africa (see Billingsley, 1968:44). ${ }^{5}$ Even those slaves forced to dissolve their marriages against their will upheld those marriages, as the slave Harry Brown showed when he called his marriage "a sacred institution binding upon me" (Queen et al., in press) and refused to remarry.

Other case histories show that even in broken families the male slave had a strong bond with his wife and children left behind. The runaway Henry Bibb wrote of his decision to escape; "To be compelled to stand by and see you whip and slash my wife without mercy when I could afford her no protection ... was more than I felt it the duty of a slave husband to endure" (Billingsley, 1968:9). J.W. Logan wrote his master, "Be it known to you that I value my freedom to say nothing of mother, brothers, and sisters more ... than my whole life (Billingsley, 1968:63). Other slaves bespeak the mourning of separation. Abrean Scriven wrote his wife, "My dear wife, for you and my children my pen cannot express the griffe I feel to be parted from you all" (Queen, et al., in press). Blassingame concludes, "In no class of American autobiographies is more stress laid upon the importance of stable families than in the autobiographies of former slaves" (1976:212).

\section{Historical Evidence}

Case histories point to a possible flaw in the original assumptions that black men were not important members of the family structure, but case histories alone cannot. provide enough evidence to reach a general conclusion about the role of black men in their families. Accordingly, the rest of my paper will establish the male role in the family from historical evidence beginning with his role in the African family, concentrating on his role in the slave family, and making mention of his role under reconstruction.

The patriarchy was the dominant mode of organization among West African tribes at the time of slave trade. The cultural organization was so strong, in fact, that the shock of kidnapping and slavery did not erase it (see Guttman, 1976:329). Evidence suggests that the culture from which slaves were uprooted has as strong a family background as European culture (Billingsley, 1968:39).

Males were predominate in African cultures. Chiefs or elders sat as judges and political leaders (Blassingame, 1976:13). They also controlled inheritance, even in polygomous marriages, to the point that they could choose their heir arbitrarily from among their sons (Rudwick quotes Herkowitz, 1971:169). Among certain tribes, such as the Ibo, the father's dominance was such that people assumed their curse would render a child useless for life (Billingsley, 1968:45). In general, women left their home to live with their spouse in his family compound (Billingsley, 1968:42). Billingsley quotes Haskell in conclusion:

The most striking feature of African family and community life was the strong and dominant place assumed by the men.... The children were provided a quality of care and protection not common to modern societies for they belonged not alone to their father and mother, but also and principally to the wider kin group (1968:40).

Most, if not all, slaves had been totally separated from their families and part of their efforts to adapt to the new environment likely centered on establishing families and close friends. The plantation owners were well aware of the benefits they could derive from encouraging strong black families. Blassingame claimed that the southern plantation was unique in allowing the development of a monogomous slave family (1976:77).

In general, the master "understood the strength of marital and family ties among their slaves well enough to see in them a powerful means of social control" (Genovese, 1974:452). Genovese claims that the more humane slave masters argued against breaking up slave unions on grounds of economic expediency because slaves worked much better when kept together (1974:457). Less humane slaveholders, however, realized that "no threat carried such force as a threat to sell the children, except the threat to separate husband and wife" (Genovese, 1974:452). It was generally recognized throughout the system then "that a slave who loved his family was likely to be less rebellious or to run away than was a single slave" (Blassingame, 1976:80).

On the slave's side, the fact that these marriages were often performed by clergymen or in churches put a moral dilemma upon the master who decided to break up a slave family. White churches struggled with this issue considerably (see Queen et al., in press). The result of all of this was that "An impressive number of slaveholders took loses they could ill-afford in an effort to keep families together" (Genovese, 1974:453). Thus the idea that the slave family was purposely destroyed 


\section{Mid-American Review of Sociology}

under slavery does not hold up well under historical scrutiny. Indeed, slaveholders realized that often the slave family was held together not by threats or moral suasion, but by affection between the spouses. If the family was to perform its desired function of contributing to social control, the owner needed an intermediary between himself and the family and this role was given to the male. "A strong man who kept his wife and children in line contributed to social peace and good order" (Genovese, 1974:489).

Furthermore, the men were also the intermediary between the overseer and other plantation workers. Fogel and Engerman point out that men occupied all managerial slots and virtually all slots for drivers and artisan crafts (Genovese, 1974:141). Women were generally seamstresses and nurses, but even here, the foreman was male (Genovese, 1974:127). Genovese concludes that females were "equal" to males only at harvest time. Indeed, planters listed families under the male head whenever possible; issues of clothing, food, etc., were done through the males, and any sale of foodstuffs by slaves was handled by the male $(1974: 142)$.

One must conclude then that by using the slave family as an administrative and reproductive unit, and by appointing the male head of the household as the intermediary for that unit, white owners had a vested interest in maintaining a relatively strong role for the black male. Therefore, strong measures were taken to insure black marriages. This required residential stability, which led to complex kin patterns among the slave population (Weatherall, 1981:303; Kulikoff, 1978:451). When slave families were broken, the actions of their owners bespeak their feelings toward the importance of strong family units (see Guttman, 1976:286-293). They knew the importance of the family not only for themselves, but for the slaves. Runaways were hunted not only in their own area, but in the area to which their families had been sold (Fogel and Engerman, 1974:143). It seems that whites not only recognized strong family patterns revolving around a male head, but actively and conscientiously promoted them. But, even so, did whites undermine black male authority in a more indirect sense through sexual exploitation of black women? It seems less likely than one would assume.

Genovese points out that the discipline problem forbade any such attempt to undermine the family, and discipline was the decisive factor for action in slave society. Further, historical and demographic
Matriarchy Under Slavery

data do not support the contention that white exploitation of black women was rampant. Stampp points out that much miscegenation was due to men of the non-slaveholding class outside of the system (see Stampp, 1956:353). Fogel and Engerman, in a demographic analysis, state that the evidence shows a low incidence of mulatto children in the slave quarters $(1974: 133)$; that whites prefered lightskinned prostitutes; and the lack of black brothels prior to the Civil War indicates a lack of preference for black concubinage (Fogel and Engerman, 1974:135). They conclude that "Even if all these reports were true they constituted at most a few hundred cases" (Fogel and Engerman, 1974:131). They also point out that white culture was strongly affected by attitudes limiting sexual activity.

There were also concrete reasons for not exploiting black women. Overseers lost their jobs (Fogel and Engerman, 1974:134) and white women were infuriated at the prospect (Blassingame, 1976:84). In addition, most whites recognized that black men frequently protected their women violently in the face of such actions. Simply put, whites knew it was dangerous for a number of reasons (Blassingame, 1976:88).

While concubinage was a problem, evidence suggests that it was not the overwhelming problem some historians have led us to believe. The widespread belief may be due to abolitionist propaganda, social values that were broken provoking outrage, or to black movements.

Slaveowners often argued that black sexual mores were so lax that they could not be trusted to form their own families. This argument also fails under analysis. Fogel and Engerman (1974:138) show that the age of first birth ranged from 15-24 years of age; not likely in a culture without sexual ethics or birth control. The mean age for marriage was 22.5 and the median age was 20.8. Fogel and Engerman conclude that, "for a wellfed, non-contraceptive population in which women are fecund after marriage, only abstinence would explain the relative shortage of births in the late teens" (1974:138). Guttman also gives support for this viewpoint, stating that most women on the plantation he studied had all their children by one father (1976:60).

If black promiscuity was less active than has been claimed, where did this prejudice arise? Part of the explanation could be attributed to slaveholders' asserting their moral superiority, but there seem to be more concrete reasons dating back to slaves' arrival from Africa. When they were first introduced to America, many slaves attempted to form polygamous unions similar to those to which they were accustomed (Guttman, 1976:331). Also, they were outside the system of white moral controls. Blassingame states: 
An imperfect understanding of the unnatural, puritanical code of their masters freed blacks from the unsuperable guilt complexes that enslaved nineteenth century white Americans in regard to sex (1976: 85).

The assumption that blacks were promiscuous may have grown from both the early attempts to establish polygamous relationships and from the comparatively lax, but more healthy, black sexual norms. Gilmore (1978:152) also makes this point: "The slave was neither an abandoned sexual hedonist nor a nuerotic puritan glorifying the frigid women."

Genovese writes that affection was the factor keeping families together (1974:87), and there seems to be some value attached to fidelity because Guttman found that it was expected after marriage even from men $(1976: 67-68)$. This value was so strong that violence, even murder, arose from suspected infidelity (Guttman, 1976:67).

Certainly, then, neither the myth of widespread white exploitation nor of black promiscuity was true. In fact, as Fogel and Engerman conclude, the "contention that the slave family was undermined by ... widespread promiscuity... is as poorly founded as the thesis that masters were uninhibited in their sexual exploitation of women" (1974:134).

White misunderstanding, the system of slavery itself, and cultural shock did leave their marks on the slave family, especially the males' role in it, but these marks were not those of ruin, but of unique adaptation. Blassingame states, the "typical slave used his wits to escape from work or punishment, preserved his manhood in the quarters, feigned humility, identified with the master and worked industriously only when treated humanely" (1976:216). As Guttman (1976: 325) put it, "the development of slave culture was not the mere consequence of slave treatment."

An early adaptation was the assimilation of the norm of the nuclear family (Queen et al., in press) by those African groups not used to one. The two parent household was ideal (Guttman, 1976: 325) and the average age difference between husband and wife was three years (Fogel and Engerman, 1974:139), much like contemporary unions.

After this, adaptation took unique forms. Blacks were strict disciplinarians (Queen et al., in press) in spite of white doting of black children. This was largely due to the fact that they knew discipline was important to the master, but it was also likely that what went on in the slave quarters often had to be kept from the master. Blassingame states that in the quarters black males often castigated their owners, became providers and protectors, and exercised authority, while he was meek and obedient only in the fields where his children seldom saw him (1976:100). It was fairly easy to dodge the master or overseer much of the time on large plantations.

Virtually all slaves and free blacks married (Guttman, 1976:270). Group pressure enforced the marital norm (Guttman, 1976:70). If a man made a woman pregnant he was expected to offer to marry her or face the consequences of social ostracism. (Gilmore, 1978:153). Once married, men gained status with the family in a variety of ways. Men were respected for their physical strength, courage, and compassion (Blassingame, 1976:102). Especially important was adding foodstuffs to the family's supply by hunting, trapping, fishing, gardening, and sometimes raising livestock (Blassingame, 1976:92).

In accomplishing this the male slave played a significant role in meeting his family's needs of daily subsistence, and may have offset nutritional deficiencies in their diet (Genovese, 1974:486). These activities gave the husband some status (Genovese, 1974:489). Indeed, hunting and learning to trap became symbols of manhood and slave boys eagerly awaited their turn to learn (Genovese, 1974:487). Before that, children were attended to by their fathers with songs, stories, and gifts (Blassingame, 1976:95). Men also built furniture for the family or roomed off the cabin for privacy. Blassingame states, "The slave who did such things for his family gained not only the approbation of his wife, but also gained status in the quarters (1976:92).

Another route to status for men was to successfully fill the difficult role of protector. Guttman found that men who protected their women from beatings and exploitation often paid with their own beatings or with their lives (1976:485). He claims that these actions were not infrequent $(1976: 484)$, and concludes that "In view of the risks, the wonder is not that more black men did not defend their women but that so many did, especially since the women had to caution restaint or risk their men's lives" (1976:485).

A male also took the initiative in preserving his family in case it was somehow broken. Even the sale and forced breakup of families did not successfully destroy the family. Often masters granted passes to men to visit families on other plantations although sometimes at infrequent intervals (see Queen et al., in press). The infrequent visit 


\section{Mid-American Review of Sociology}

became more important in some respects because they became minor celebrations (Blassingame, 1976:95). Husbands without passes often visited families by stealth (see Queen et al., in press).

In the event of a total breakup, remarriage led to new male role models. Guttman expresses the importance slaves attached to this. "Stepfathers everywhere reportedly treated their newly acquired children as if they had been their own" (Guttman, 1974:486). If there were no remarriage an uncle, cousin or older brother often gave children a male role model. Runaways had to overcome their feelings toward their family before they could effect their escape. Sometimes this was the biggest obstacle (Blassingame, 1976:111). Blassingame further states, "The simple threat of being separated from his family was generally sufficient to subdue the most rebellious 'married' slave" (1976:80). Of those who decided to escape, Guttman writes, "Surviving letters to kin reveal their loneliness and guilt" (1976:265). Often though, slaves gained the freedom of their family or, if single, married after escape, as did Fredrick Douglas (Willie, 1981:6).

The evidence exhibits the male's importance within the family. Corrobating such evidence, Fogel and Engerman state that "It is not true that the typical slave family was matriarchal in 'form' and that the 'husband' was at most his wife's assistant. Nor is it true that the male slave's only crucial function was that of siring offspring" (1974:141). And speaking about the male role under slavery, Genovese puts it more forcefully, "A terrible system of human oppression took a heavy toll of its victims, but their collective accomplishments in resisting the system constitutes a heroic story" (1974:491).

A final argument offered to support the idea that slavery destroyed the black family and male's importance in it is that the families disintegrated immediately after emancipation, or, at least those families that lacked much cohesiveness lost the little they had. Neither of these arguments seems valid.

With the end of slavery, although unprotected by law, most slave families (at least in Virginia) had two parents and most older couples had lived in long-lasting unions (Guttman, 1976:8). Those families without these advantages made efforts to patch themselves together by looking for each other (Genovese, 1974:493). As Washington writes of his father "As soon as freedom was declared, he sent for my mother to come to the Kanawha Valley in West Virginia" (Washington, 1965:30-31); or Lucinda Davis "I don't know where I been born. Nobody never did tell me. But my mammy and pappy get me after de know where I was and I know den whose child I is" (Yetman, 1970:82).
Matriarchy Under Slavery

Newly emancipated blacks began to demand rights and privileges that would strengthen the family. They demanded wages high enough to support their entire families (Queen et al., in press), and went even further. Genovese states:

Every student of the Union occupation and early reconstruction has known the rush of the freedman to legalize their marriages; of the widespread desertion of the plantation by whole families, or the demands by men and women for a division of labor that would send the women out of the fields and into the homes... and especially of the heart rending efforts of thousands of freedmen to find long-lost loved ones all over the south (1974:451).

Both sexes worked to strengthen the position of blacks. One of the first attempts to do so was the organization by Georgian black men into a "Son's of Benevolence" society that defended females (Guttman, 1974:485). Women deferred to their husbands when it was politically or economically expedient for blacks as a group to do so, but worked long and hard for important measures when necessary (Guttman, 1974:490).

From the records of the early reconstruction period, it seems that blacks made a concerted effort to unite, maintain, and strengthen their families. There were failures, but the effort to reunite was widespread. Black men and black families in general left slavery much stronger than we have been led to believe. The ex-slaves' culture under slavery strengthened him to face the degradations and hardships ahead.

\section{Conclusions and Suggestions}

Two concrete conclusions can be drawn from the literature. First, Genovese writes of black males, "If many lived up to their assigned irresponsibility others, probably a majority, overcame all obstacles and provided a positive male image for their wives and children" (1974: 492). Black men did provide strong role models. Second, on the strength of the black family in general Genovese writes:

A remarkable number of women did everything possible to strengthen their men's self-esteem and to defer to their leadership. What has usually been viewed as a debilitating female supremacy was in fact a closer approximation to a healthy sexual equality than was possible for whites and perhaps even for many post-bellum blacks. The men did not 
play the provider in the full and direct sense, but did everything they could to approximate it. They could have scored few successes without the sympathic cooperation of their women many-by no means all-of whom yeilded their own prerogatives (1974:500).

Genovese concludes that the males and their families overcame tremendous hardships remarkably well $(1974: 486){ }^{6}$

What are the contemporary pressures affecting the black family and the male's role in it? Several considerations may be made but a possible answer seems to lie in age-old prejudice and, to an extent, the social system within which we live. For example, Blackwell (1975: 40) estimates that 70 percent of all black family units have two parents living in the home and Willie, in 1981 after Reaganomics had begun, writes that eight or nine out of ten black men still held jobs and six or seven out of ten black families are two parent families (1981:11). This contrasts with the stereotype portrayed by Moynihan and others.

Essentially, however, the black suffers a similar plight under modern capitalism as he did under slavery-he controls virtually none of the means of production (possibly even labor itself since he is a minority). The black has not changed his position in the mode of production. His status is still low and the economic system of which he is a part has worked to keep his status low. New economic measures, probably the only answer to black problems, may have a lasting effect; because if black men and their families are not weak, then the "problem" with black Americans lie in their position in the class structure.

However, further studies on epochs in black American history are necessary. Was the family really strong in West Africa during the slave trade? Did the failures and setbacks of reconstruction, Jim Crow, and Jim Lynch hurt the black family? How have blacks fared under the influences of the Great Depression, rapid urbanization, and the struggles of the 1950s and 1960s? Are there still unique pressures on the black family? The answers to these questions may lead to an explanation of the continuing racism against, and problems of, the black American.

\section{FOOTNOTES}

1. A reviewer has suggested that Oscar Lewis' thesis on the "culture of poverty" be included in this discussion. However, I have left out Lewis for two reasons: (1) his thesis is so widely criticized that citing him would necessarily be coupled with another criticism of his work, which is already borne in the paper, and
(2) I do not wish to equate Stack's extended family thesis with Lewis, thereby possibly confusing or misleading the readers.

2. See Merton on Innovation, 1968:143-149.

3. One of these ideals was the high value placed on monogomous marriage. Slave religious leaders officiated at marriage ceremonies either with the consent of the owner or in spite of it (Guttman, 1976:274). The white aristocrat diarist Mary Chestnut, explains the importance placed on marriage: "The slave preachers requires them to keep the commandments. If they are not married and show they ought to be-out of church they go" (Guttman, 1976:70).

4. For discussions on ressentiment see Nietzsche (1968:593) and Weber (1978: 492-499).

5. Experts disagree on how much of the pattern of African life was destroyed by the cultural shock of kidnapping and slavery. Some (e.g., Frazier, 1948; Elkins, 1963; Glazer and Moynihan, 1963) claim that any elements of African life were lost in the passage to America and that no institutions have risen since to stabilize black culture in the United States. Others, however (e.g., Herskovits, 1941; Billingsley, 1968; Nobles, 1974) believe that much of African culture survived. I believe that the African elements incorporated into slave religious practice reveals cultural resilience. There is no reason to believe that family traditions were less central in African life than were religious beliefs.

6. Cherlin also rejects the "remnant of slavery" thesis and offers demographic evidence that the major changes in the black family have occurred during the twentieth century and, for the most part, since World War II (1981:103-104).

\section{REFERENCES}

Baechler, J.

1970 Revolution. New York: Harper \& Row.

Billingsley, A.

1968 Black Families in White America. Englewood Cliffs: Prentice-Hall, Inc.

Blackwell, J.E.

1975 The Black Community: Diversity and Unity. New York: Dodd, Mead, and Company.

Blassingame, J.W.

1976 The Slave Community. New York: Oxford University Press.

Catton, B.

1961 The Coming Fury. Garden City: Doubleday \& Company.

Cherlin, A.J.

1981 Marriage, Divorce, Remarriage. Cambridge: Harvard University Press.

DeBois, W.E.B.

1903 The Negro Church. Atlanta: Atlanta University Press.

Douglas, F.

1962 Life and Times of Fredrick Douglas. New York: McMillan. 
Elkins, S.M.

1963 Slavery: A Problem in American Institutional and Intellectual Life. Chicago: University of Chicago Press.

Fogel, R.W. and S.L. Engerman

1974 Time on the Cross. Boston: Little, Brown \& Co.

Frazier, E.F.

1948 The Negro Family the the United States. New York: Citadel Press.

Genovese, E.D.

1974 Roll, Jordan, Roll. New York: Random House.

Gilmore, A.T

1978 Revisiting Blassingame's The Slave Community. Westport: Greenwood Press.

Glazer, N. and D. Moynihan

1963 Beyond the Melting Pot. Cambridge: MIT Press.

Guttman, H.G.

1976 The Black Family in Slavery and Freedom 1750-1925. New York: Pantheon Books.

Herskovits, M.J.

1941 The Myth of the Negro Past. New York: Harper. and Row.

Kulikoff, A.

1978 "The Beginnings of the Afro-American Family in Maryland," in Michael Gordon (ed.) The American Family in Social-Historical Perspective (2nd ed.). New York: St. Martins Press.

Killian, L.

1975 The Impossible Revolution. New York: Random House.

Leibow, E.

1967 Tally's Corner. Boston: Little, Brown.

Marx, K.

1978 Capital (Vol. 1). Moscow: Progress Publishers.

Merton, R.K.

1968 Social Theory and Social Structure. New York: The Free Press.

Moses, W.J.

1982 Black Messiahs and Uncle Toms. London: The Pensylvania State University Press.

Nietzsche, F.

1968 The Portable Nietzsche (trans. by Walter Kaufman) New York: Viking Press.

Nobles, W.W.

1974 "African Root and American Fruit: The Black Family," in Journal of Social and Behavioral Sciences 20:52-64.

Queen, S.A., R.W. Habenstein, and J. Quadagno

In The Family in Various Cultures. New York: Harper and Row. Press

Rainwater, L. and W.L. Yancy

1967 The Moynihan Report and the Politics of Controversy. Cambridge: The M.I.T. Press.

Rosen, $\mathrm{H}$

1977 Pathway to Piaget. Cherry Hill: Postgraduate International, Inc.
Rudwick, B.

1971 Black Matriarchy: Myth or Reality. Belmont: Wadsworth Publishing Co.

Spradley, J.P.

1980 Participant Observation. New York: Holt, Rinehart, and Winston.

Stampp, K.M.

1956 The Peculiar Institution. Toronto: Random House and Alfred A.

Stack, C. Knopf.

1974 All Our Kin. New York: Harper and Row.

Washington, B.T.

1965 Up From Slavery. New York: Dell.

Weatherall, C.

1981 "Slave Kinship: A Case Study of the South Carolina Good Hope Plantation 1835-1856," in Journal of Family History (Fall, 1981 294-308).

Weber, $M$

1978 Economy and Society. New York: Irvington.

Willie, C.V.

1981 A New Look At Black Families (2nd ed.) Bayside: General Hall, Inc. Yetman, N.R.

1970 Life Under the "Peculiar Institution" New York: Holt, Rinehart, and Winston. 